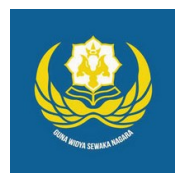

Jurnal Analogi Hukum

Journal Homepage: https://ejournal.warmadewa.ac.id/index.php/analogihukum

\title{
Upaya Pekerja Outsourcing Terhadap Pemutusan Hubungan Kerja Atas Pelanggaran Kontrak Kerja
}

\author{
I Putu Agus Tirta Yasa*, I Nyoman Putu Budiartha dan Ni Made Puspasutari Ujianti \\ Universitas Warmadewa, Denpasar-Bali, Indonesia \\ *tirtayasa@gmail.com
}

\begin{abstract}
How To Cite:
Sumardiana, I, N., Budiartha, I, N, P., Arini, D, G. D. (2020). Upaya Pekerja Outsourcing Terhadap Pemutusan Hubungan Kerja Atas Pelanggaran Kontrak Kerja. Jurnal Analogi Hukum, 2 (2). 192-196. Doi: https://doi.org/10.22225/ah.2.2.1926.192-196
\end{abstract}

\begin{abstract}
In its development, every industry today is a business activity that produces a large economy that requires a lot of labor. In its rules namely Law No. 13 of 2003 which applies primarily in labor matters has been established as a rule for systematically running the business activities of the company. The formulation of the problem in this study is 1) How do acts of violation of termination of employment against outsourcing workers? 2) What are the efforts of outsourcing workers who violate the employment contract and are affected by Termination of Employment? This study uses normative legal research methods, uses the statutory approach and conceptual approach, examines primary legal materials, secondary legal materials, and tertiary legal materials and uses legal material collection techniques by studying literature, reading literature and related internet pages. Outsourcing is a term that refers to the authority of the job to employ every community who wants to move in the company's business. Outsourcing workers are intended as workers who have joined certain companies to carry out a business activity in which of course there are terms and conditions governing the management of these workers, mentioned in the employment contract. The rules contained in each work contract allow there is no crime against business ventures and layoffs if there is fraud or breach of contract outsourcing workers in running a business, it is in accordance with the Manpower Act.
\end{abstract}

Keywords: Employment contract violations, outsourced workers, termination of employment

\begin{abstract}
Abstrak-Dalam perkembangannya, setiap industri sekarang ini merupakan kegiatan bisnis yang menghasilkan perekonomian besar hal tersebut membutuhkan tenaga kerja yang sangat banyak. Dalam aturannya yakni Undang-undang No. 13 tahun 2003 yang berlaku utamanya dalam permasalahan ketenagakerjaan sudah ditetapkan sebagai aturan guna mensistematis jalannya kegiatan tata kerja bisnis perusahaan. Adapun rumusan masalah dalam penelitian ini adalah 1) Bagaimana tindakan pelanggaran PHK terhadap pekerja outsourcing? 2) Bagaimana upaya pekerja outsourcing yang melanggar kontrak kerja dan terkena PHK? Penelitian ini menggunakan metode penelitian hukum normatif, menggunakan pendekatan perundang - undangan dan pendekatan konseptual, mengkaji dari bahan hukum primer, bahan hukum sekunder, dan bahan hukum tersier serta menggunakan teknik pengumpulan bahan hukum dengan studi kepustakaan, membaca literatur dan halaman internet terkait. Outsourcing merupakan istilah yang merujuk pada wewenang pekerjaan tersebut untuk memperkerjakan setiap masyarakat yang ingin bergerak dibidang bisnis perusahaan. Pekerja Outsourcing dimaksudkan sebagai pekerja yang telah ikut bergabung dengan perusahaan tertentu untuk menjalankan suatu kegiatan bisnis didalamnya tentunya terdapat syarat-syarat serta ketentuan yang mengatur tata kelola pekerja tersebut, disebutkan dalam kontrak kerja. Aturan-aturan yang terdapat disetiap kontrak kerja memungkinkan tidak adanya kejahatan terhadap usaha bisnis dan adanya PHK jika terdapat kecurangan ataupun pelanggaran kontrak pekerja Outsourcing dalam menjalankan suatu bisnis, hal tersebut sesuai dengan UU Ketenagakerjaan.
\end{abstract}

Kata kunci: Pekerja outsourcing, Pemutusan Hubungan Kerja, Pelanggaran Kontrak Kerja

\section{Pendahuluan}

Di indonesia sendiri secara garis besar jumlah penduduk yang banyak dengan tidak dipungkiri jika angka pengangguran di era saat ini semakin meningkat, pemerintah memproses segala bentuk kegiatan baik dalam konteks tata kelola suatu kegiatan usaha setiap masyarakat serta pihak-pihak luar yang berkehendak membuka bisnis di Indonesia dengan peranan 
sebagai membuka peluang kerja untuk masyarakat Indonesia secara keseluruhan mendapatkan kemakmuran segala pihak. Industri yang semakin pesat secara global membuka peluang bisnis disetiap negara untuk membuka kontrak-kontrak kerja dengan maksud memberantas pengangguran yang ada di negara tersebut, layaknya negara Indonesia hal tersebut membuat peluang untuk menjalankan sistem ketenagakerjaan.

Ketenagakerjaan merupakan masalah yang sangat vital karena terkait langsung dengan kesejahteraan hidup masyarakat. Oleh karena itu, ketenagakerjaan tidak dapat dilepaskan dari bidang yang lain seperti sosial, politik, ekonomi, keamanan, dan budaya (Triyono, 2011). Outsourcing sendiri merupakan salah satu sistematis yang terstruktur dibuat oleh negara Indonesia tertuang dalam UU RI No 13 Tahun 2003 dalam pelaksaannya tentang Ketenagakerjaan.

Pekerja outsourching menjadi salah satu permasalahan dalam dinamika ketenagakerjaan Indonesia, selain terkait dengan masalah kesejahteraan pekerja hal ini juga mampu menimbulkan adanya konflik komunal di masyarakat pekerja jika terus dibiarkan (Wijaya, 2017). Perusahaan-perusahaan yang bergerak di bidang bisnis usaha/ Industri dalam pemenuhannya dapat memperkerjakan atau mencari penyedia jasa buruh melalui perjanjian-perjanjian yang dibuat secara tertulis atau disebutkan sebagai kontrak kerja sebagai kelangsungan jalannya bisnis industri tersebut. Dalam hal tersebut pemerintah ikut serta dalam mengontrol jalannya pergerakan yang melibatkan SDM dimana rakyatnya sendiri untuk mendapatkan perlindungan kerja yakni memperoleh kemakmuran serta keadilan untuk menjalankan setiap kegiatan demi pemenuhan hidupnya. UU ketenagakerjaan sebagai aturan utama dalam setiap kegiatan yang mengandung unsur SDM dalam bekerja dibidang industri bisnis, dimana hal tersebut memproteksi segala konflik-konflik ataupun kecurangan baik dari pihak bisnis terhadap perkerja serta dari pekerja terhadap pelanggaran kontak kerja mereka masingmasing.

Selama suatu pekerjaan atau kegiatan bisnis industri khususnya dijalankan di Indonesia serta memperkerjakan penduduk asli Indonesia, maka pemerintah Indonesia mengutamakan HAM pekerja dalam kegiatan tersebut. mencegah adanya konflik/ diskriminasi terhadap pekerja Indonesia guna kesejahteraan pekerja tersebut namun tetap mensistematis perkembangan perekonomian bangsa. Perusahaan yang telah menjalankan usaha bisnis industri dengan memperkerjakan tenaga kerja Outsourcing secara pemenuhannya tetap mempertanggungjawabkan segala kondisi dari tenaga kerja serta selalu berpatokan dari isi kontrak kerja sesuai dengan aturan yang berlaku secara umum, tidak menjalankan kegiatan diluar konteks kontrak serta tidak mempengaruhi dan/ atau mendampakkan hal negatif terhadap pemerintah.

Berkenaan dengan Outsourcing dimana hal tersebut ada kaitanya dengan sistem pemerintah guna mensejahterakan rakyat untuk perekonomian negara juga, maka pemerintah dalam hal ini turut serta memperlindungkan hak -hak para pekerja. Susuai aturan yang telah diberlakukan baik memperlindungakn pekerja saat sebelum bekerja dan pada masa bekerja serta sesaat setelah selesai bekerja. Ketiga aspek tersebut tentunya masuk dalam perlindungan pemerintah sesuai dengan yang dimuat dalam UU Ketenagakerjaan No. 13 tahun 2003, selain itu pemutusan/ pemberhentian yang dimaksudkan yakni pengakhiran kerja atau PHK tentukan masuk kedalam urusan pemerintah agar lebih diteliti alasan-alasan dari PHK tersebut.

UU Ketenagakerjaan menjelaskan tentang adanya perlindungan terhadap segala aspek baik terhadap pihak bisnis ataupun terhadap pekerjanya, Yang menjadi rumusan masalah dalam penelitian ini yakni

1) Bagaimana tindakan pelanggaran PHK terhadap pekerja outsourcing?

2) Bagaimana upaya pekerja outsourcing yang melanggar kontrak kerja dan terkena PHK?

Penelitian ini bertujuan untuk :

Untuk memahami secara detail penindakan atas pekerja outsourcing yang terkena PHK

Untuk mengetahui upaya yang dapat dilakukan pekerja outsourcing atas pelanggaranpelanggaran kontrak kerja yang di-PHK serta didasarkan hukum positif Indonesia.

\section{Metode}

Jenis penelitian yang digunakan dalam penelitian ini adalah jenis penelitian hukum normatif yaitu dengan melakukan pengkajiannya berdasarkan bahan-bahan hukum dari literatur dan merupakan suatu proses untuk menemukan aturan hukum, prinsip hukum, konsep hukum guna menyelesaikan masalah yang dihadapi. Sedangkan pendekatan masalah yang digunakan secara yuridis yaitu dengan 
meninjau peraturan yang berhubungan dengan permasalahan.

Adapun sumber bahan hukum yang digunakan yakni:

Bahan hukum Primer, yakni: bahan hukum yang berpusat peraturan UU yang berlaku di Indonesia: UUD RI Tahun 1945, UU No 13. tahun 2003 tentang Ketenagakerjaan, Permen No. 19 Tahun 2012 Tentang Persyaratan dalam hal Pelaksanaannya pekerja terhadap perusahaan lain, Permenaker UU No. 2 Tahun 2004 Tentang Penyelesaian Penyelisihan Hubungan Industrial, Kitab Undang-undang Hukum Perdata (KUH Per).

Bahan Hukum Sekunder yakni: bahanbahan hukum yang diperoleh dari pengkajian kepustakaan (Library Research), seperti: buku, jurnal-jurnal hukum, surat kabar, internet, dan pendapat para ahli.

Untuk memperoleh bahan-bahan hukum primer dan sekunder penulis melakukan penelitian dengan menggunakan teknik pengumpulan dengan cara membaca bukubuku, peraturan perundang-undangan serta literatur lainnya yang ada kaitannya mengenai permasalahan yang penulis bahas tentang upaya pekerja outsourcing terhadap PHK atas pelanggaran kontrak kerja di Indonesia.

Bahan hukum yang telah dikumpulkan selanjutnya diolah menggunakan metode deduktif induktif atau sebaliknya, untuk memperoleh bahan hukum yang berkualitas sesuai dengan pokok masalah yang dibahas dan akhirnya berdasarkan bahan hukum yang diperoleh dari pengumpulan maupun pengelolaan-pengelolaan tersebut di atas lalu disajikan dalam bentuk jurnal secara deskriptif.

\section{Hasil Penelitian dan Pembahasan}

\section{Sistem Penindakan PHK Kepada Pekerja Outsourcing}

Outsourcing yakni pada dasarnya pemberi jasa kerja yang dibutuhkan kepada setiap perusahaan-perusahaan besar bergerak dibidang industri dimana dalam hal tersebut adanya penyerahan wewenang untuk memperkerjakan setiap orang untuk melakukan ataupun membantu kegiatan bisnis industri tersebut utamanya pada perusahaan asing. Hal tersebut memungkinkan adanya suatu aturan yang harus memperlindungkan antara kegiatan bisnis tersebut serta perlindungkan setiap orang yang turut serta membantu kegiatan industrial dalam kontrak kerja perusahaan. Disebutkan juga sebagai pihak ketiga dalam pengelolaan sistem pekerjaan setiap orang, yakni dimaksudkan jika setiap orang akan didaftarkan kedalam perusahaan pemberi kerja ialah user ketika suatu perusahaan lain membutuhkan tenaga kerja ialah Vendor maka dalam hal tersebut User akan mengirimkan pekerjanya untuk bekerja secara kontrak kepada Vendor. Dengan kata lain sebagai pendelegasian operasi suatu pekerja dari perusahaan utama kepada perusahaan lain dan/ atau perusahaan penerima jasa Outsourcing secara sistematis suatu proses bisnis industrial dan kegiatan-kegiatan yang tertera pada kontrak kerja (Lalu, 2003).

Aturan mengenai tatanan Outsourcing sudah diberlakukan dibeberapa UU dan aturan lain, hal tersebut secara keseluruhan perlu dimaksimalkan dari masa ke masa selanjutnya dikarenakan dari tahun ke tahun perkembangan zaman selalu berubah dikaitkan terhadap industrial dan kontrak kerja dari kegiatankegiatan perusahaan yang memperkerjakan masyarakat yang tentunya diperlindungkan pemerintah. Salah satu ketentuan mengenai tata kelola pekerja Outsourcing ini yakni pada PERMEN No. 19 Tahun 2012 dimana dijelaskan suatu syarat umum untuk memperkerjakan masyarakat serta dalam pelaksanaannya terhadap penyerahanpenyerahan yang dapat berpacu untuk suatu alih daya yakni pemborongan terhadap pekerjapekerja dan penyediaan jasa-jasa pekerja.

Terdapat beberapa hak para pekerja Outsourcing yang telah menjalani pekerjaannya didalam suatu perusahaan yakni atas pembayaran tambahan dalam keperluannya dimana hal tersebut jika pekerja melakukan kegiatan ekstra dalam usaha bisnis tersebut, sifat dari kontrak kerja yang telah diajalankan pekerja bersifat sementara atau pekerjaan tersebut hanya berlaku sesuai kontrak dan bisa diperpanjang jika kedua belah pihak berkehendak, hak lainnya yakni perusahaan tempat bekerja tidak membeda-bedakan dengan pekerja yang setara ataupun dalam hal ini disebutkan sebagai diskriminasi, tetap memperoleh HAM nya secara utuh, serta setiap pekerja diberlakukan adil dan/ atau kepastiankepastian dalam penjamin kontrak kerja yang telah berjalan sampai kegiatan tersebut usai. Mengenai kewajiban pekerja Outsourcing tidak ada perbedaan dengan pekerjaan-pekerjaan lain di berbagai urusan yakni selalu bekerja dengan tanggung jawab penuh yang diperhatikan oleh diri sendiri dan/ atau dari pihak lain serta bekerja secara utuh sesuai isi dari kontrak kerja dan dilarang menjalankan kegiatan diluar dari itu. 
Berkenaan dengan pelanggaran yang telah dilakukan oleh pekerja Outsourcing maka dalam hal ini adanya sistem PHK oleh perusahaan penerima jasa (Vendor) terhadap pekerjanya yang telah berkontak kerja, baik hal tersebut diutus dari perusahaan itu sendiri karena adanya konflik yakni terdapatnya penipuan, kecurangan yang berdampak mengacaukan kegiatan usaha bisnis perusahaan seperti pencurian, adanya keterangan atau datadata palsu, pekerja memiliki naluri sebagai penjahat baik secara nyata maupun naluri seperti pecandu narkotika atau zat-zat berbahaya lain, terjadinya tindakan asusila oleh keperja yang merugikan perusahaan. PHK Dilihat juga dari aspek-aspek lain yakni bisa saja dari keinginan pekerja itu sendiri, dan atas tidak adanya kelanjutan dari kontrak kerja ataupun disebut sebagai perpanjangan kontrak kerja.

Aturan yakni UU Ketenagakerjaan yang salah satu perannya berfungsi sebagai perlindungan terhadap pekerja Outsourcing yang telah menjalankan kegiatan di perusahaan dimana pekerja tersebut telah menyetujui perikatan kontrak kerja. Beberapa hal yang tertuang didalamnya yakni : (Soepomo, 2003)

Perlindungan secara bentuk ekonomisnya, yakni disebutkan sebagai penghasilan yang didapatkan kepada pekerja baik sesuai kontrak maupun pembiayaan tambahan terhadap pekerja yang telah melakukan pekerjaannya sesuai dengan kelebihan kerja dalam bentuk positif kepada perusahaannya dan memperoleh hak lebih untuk bonus yang didapatkan.

Perlindungan secara bentuk sosiologisnya, yakni adanya suatu jaminan-jaminan yang berhak didapatkan selama menjadi pekerja kontrak Outsourcing yang memungkinkan sarana khusus untuk perlindung baik dalam bentuk fisik ataupun batin seperti kesehatan serta keselamatan bekerja.

Perlindungan dalam bentuk teknisnya, yakni memperoleh keamanan dan kenyamanan utuh dari setiap bahayanya pekerjaan yang dilakukan pekerja, dimaksudkan dalam hal ini sebagai perlengkapan yang sesuai standar didapatkan untuk melaksanakan pekerjaan.

\section{Upaya Hukum Bagi Pekerja Outsourcing Yang Di-PHK}

Dalam terjadinya suatu kontrak kerja dimana setiap pekerja mendatangani dari sekian isi dari yang tertera di kontrak kerja tersebut serta bertanggung jawab atas kontrak kerja mereka. Kontrak kerja tersebut yakni salah satu perjanjian yang tertulis seperti yang diatur pada KUH Per 1320 yang sama atas dasar syarat sah suatu kontrak/ perjanjian dalam konteks pekerjaan dimuat juga pada UU Ketenagakerjaan No. 13 Tahun 2003 yakni pada ketentuan umum di pasal 1 angka 14, dimaksudkan bahwa perjanjian/ kontrak kerja tersebut merupakan suatu ikatan dari pekerja terhadap suatu perusahaan pemberi kerja secara konkrit menuai dari syarat kerja dan/ atau hakhak serta kewajibannya pekerjaan tersebut. Sama seperti pada KUH Per dimana syarat sahnya perjanjian yang legal yakni memang suatu kesepakatan yang dikehendaki semua pihak, setiap orang atau beberapa pihak yang terhubung dalam ikatan perjanjian merupakan orang yang cakap hukum, terdapat perihal yang menyangkut kepentingan semua pihak yang berdasarkan tindakan/ kegiatan yang jelas utamanya dibenarkan oleh hukum, serta yang terpenting yakni kegiatan/ tindakan yang diperikatkan dari semua pihak tersebut tidak suatu kegiatan yang melanggar norma ataupun hukum-hukum yang berlaku. (Wijayanti. Asri, 2009: 86)

Tidak dipungkiri jika setiap kontrak kerja memiliki sanksi dimana berdampak langsung terhadap setiap pekerja yang telah menyetujui kontrak tersebut, beberapa fase terdapat pekerja yang khususnya telah melanggar kontrak kerja dan/ atau telah menyalahi konteks kerja dimana hal tersebut merugikan pihak-pihak lain yang terlibat didalamnya. Dengan hal tersebut memungkinkan perusahaan menindak lanjuti dari setiap konflik-konflik yang telah diperbuat pekerja dan terdapat wewenang jika perusahaan tersebut memang harus menindak keras seperti PHK ke pekerja tersebut. Beberapa hal yang secara umum sering terjadi ketika suatu perusahaan memberikan PHK ke setiap kontrak kerja dari pekerja-pekerjanya dan hal tersebut diperlukannya tindak lanjut bahkan perlu dianalisa pembenaran yang membutuhkan pembuktian juga, yakni pekerja tersebut didapati telah berbuat tindakan/ unsur secara pidana dimaksudkan seperti melakukan pencurian atau pembobolan data-data dari perusahaan yang membuat dampak buruk perusahaan, pekerja melakukan kesalahan fatal dan secara rinci telah melanggar kontrak kerjanya, pekerja memang berniat mengundurkan diri dimaksudkan jika ada pekerja tersebut tidak sanggup lagi menjalankan kegiatan-kegiatan yang harus dijalankan sesuai isi kontrak kerja, perusahaan bernasib buruk seperti mengalami pailit/ rugi besar yang menyebabkan PHK besar-besaran ke setiap pekerjanya, beberapa kontrak kerja dari pekerja 
tersebut memasuki masa pensiun dan/ atau tidak adanya penambahan kontrak kerja, dan yang terakhir yakni pekerja terkena PHK ketika pekerja tersebut telah menjalankan kegiatan di perusahaan tersebut selama 5 tahun berturutturut (Subekti, 2001). Selain adanya tindak PHK yang diberikan oleh perusahaan, hal lain yang terdapat pada kontrak kerja jika adanya tindakan negatif dari pekerja tersebut yang mempengaruhi isi kontrak yakni sanksi-sanksi tegas seperti sanksi dalam bentuk administratif, sanksi perdata yang berhubung langsung dengan beberapa pihak, serta sanksi pidana seperti yang ada pada aturan-aturan KUHP jika terjadi tindakan/ unsur pidana didalamnya.

Terdapat juga kasus akan pekerja yang tidak terima di PHK karena berbagai alasan, hal tersebut telah diproses oleh hukum dan termuat juga dalam UU Ketenagakerjaan serta PERMEN. Berkenaan dengan upaya-upaya yang dapat dilakukan pekerja untuk menyeleksi apakah memang harus di PHK atau tidak dapat dilihat dari aspek hukum, disebutkan jika PHK dalam setiap kontrak kerja yang diberikan langsung oleh pekerja yang telah melanggar kontraknya tersebut harus diserahkan data-data PHK ke P4D yakni Panitia Daerah guna diberikannya izin untuk putusannya dari PHK yang diberikan. Jika izin tidak diberikan maka PHK batal demi hukum, hal tersebut menjadikan salah satu upaya dalam setiap pekerja agar tidak adanya tindakan semenamena dari perusahaan untuk memecat pekerja demi memperoleh keuntungan pribadi dan berdampak langsung ke setiap pekerja didalamnya. Selain itu terdapat Penyelesaian yang dapat dilakukan pekerja untuk mendapatkan haknya kembali dalam prosesnya terkena PHK yakni diluar pengadilan seperti Arbitrasi, Bipartit, Mediasi, dan Konsiliasi.

\section{Simpulan}

Dalam pelakasanaan outsourcing itu sendiri telah membantu program pemerintah untuk mengurangi jumlah pengangguran yang ada di Indonesia, dengan adanya perusahaan penerima jasa pekerja serta kepada perusahaan pemberi kerja. Berkenaan dengan alih daya SDM yang menjadi karyawan di setiap perusahaan yang bergerak dibidang industrial utamanya tetap berlandaskan aturan-aturan yang berlaku dan hal tersebut didukung oleh pemerintah. Seperti halnya suatu pekerjaan lain, kontrak kerja menyangkut setiap aspek kerja yang memungkinkan kesetiap pekerja yang telah menyetujui setiap janji-janji kerja untuk melaksanakan setiap pekerjaan sesuai isi kontrak, bertanggung jawab penuh dan/ atau berkewajiban atas pekerjaannya. Demikian dengan hak-hak yang diperoleh, perusahaan bertanggung jawab atas pekerja yang telah bergabung didalam kegiatan-kegiatan tersebut serta pemerintah mengontrol tindakan perusahaan itu. Terdapat motif dimana para pekerja menadapatkan hak lebih atas pekerjaan yang sepantasnya didapatkan namun terdapat juga tindakan PHK yang diberikan dalam setiap pelanggaran-pelanggaran yang berdampak buruk terhadap kotrak kerja dan perusahaannya. UU Ketenagakerjaan telah memuat segala aspek yang terkandung untuk memberikan keadilan dan kenyamanan atas semua pihak yang tergabung di kontrak kerja, yakni terdapat sanksi-sanksi tegas untuk memfasilitasi segala pelanggaran kontrak kerja. Adanya upaya hukum untuk setiap pekerja outsourcing untuk memperoleh haknya dari PHK yang diberikan guna mengetahui maksud dari PHK yang diberikan, hal tersebut mencegah adanya tindakan semena-mena yang diberikan kesetiap pekerja outsourcing.

\section{Daftar Pustaka}

Hukum Kerja Hukum Ketenagakerjaan Bidang Hubungan Kerja, 2007, Jakarta: PT. Raja Grafindo Persada,

Lalu, H. (2003). Proses Bisnis Outsourcing. Jakarta: Gramedia Widiasarana Indonesia.

Soepomo, I. (2003). Hukum Perburuhan Bidang Hukum Kerja. Jakarta: Djambatan.

Subekti, R. (2001). Aneka Perjanjian Kontrak Kerja. Jakarta: PT Intermasa.

Triyono. (2011). Outsourcing Dalam Perspektif Pekerja Dan Pengusaha. Jurnal Kependudukan Indonesia, 6(1), 45-62.

Wijaya, A. A. M. (2017). Dinamika Ketenagakerjaan Di Indonesia: Penghapusan Sistem Outsourching (Kajian Undang-Undang Nomor 13 Tahun 2003 tentang Ketenagakerjaan). Spirit Publik, 12(2), 94-105. Retrieved from. 